\title{
Technetium-99m Transport and Immobilisation in Porous Media: Development of a Novel Nuclear Imaging Technique
}

Claire L. Corkhill ${ }^{1}$, Jonathan W. Bridge ${ }^{2,3}$, Philip Hillel ${ }^{4}$, Laura J. Gardner ${ }^{1}$, Steven A. Banwart ${ }^{3}$ and Neil C. Hyatt ${ }^{1}$

${ }^{1}$ The Immobilisation Science Laboratory, Department of Materials Science and Engineering, The University of Sheffield, UK.

${ }^{2}$ The Centre for Engineering Sustainability, School of Engineering, University of Liverpool, UK.

${ }^{3}$ Kroto Research Institute, Department of Civil and Structural Engineering, The University of Sheffield, UK.

${ }^{4}$ Department of Nuclear Medicine, Sheffield Teaching Hospitals NHS Foundation Trust, Sheffield, UK.

\section{ABSTRACT}

Technetium-99, a $\beta$-emitting radioactive fission product of ${ }^{235} \mathrm{U}$, formed in nuclear reactors, presents a major challenge to nuclear waste disposal strategies. Its long half-life $\left(2.1 \times 10^{5}\right.$ years) and high solubility under oxic conditions as the pertechnetate anion $\left[\mathrm{Tc}(\mathrm{VII}) \mathrm{O}_{4}\right]$ is particularly problematic for long-term disposal of radioactive waste in geological repositories. In this study, we demonstrate a novel technique for quantifying the transport and immobilisation of technetium-99m, a $\gamma$-emitting metastable isomer of technetium-99 commonly used in medical imaging. A standard medical gamma camera was used for non-invasive quantitative imaging of technetium-99m during co-advection through quartz sand and various cementitious materials commonly used in nuclear waste disposal strategies. Spatial moments analysis of the resulting ${ }^{99 \mathrm{~m}} \mathrm{Tc}$ plume provided information about the relative changes in mass distribution of the radionuclide in the various test materials. ${ }^{99 \mathrm{~m}} \mathrm{Tc}$ advected through quartz sand demonstrated typical conservative behaviour, while transport through the cementitious materials produced a significant reduction in radionuclide centre of mass transport velocity over time. Gamma camera imaging has proven an effective tool for helping to understand the factors which control the migration of radionuclides for surface, near-surface and deep geological disposal of nuclear waste.

\section{INTRODUCTION}

In Europe and the US, the preferred long-term disposal solution for nuclear waste is burial in a deep geological disposal facility (GDF) [1]. During the operational lifetime of such facilities $\left(\sim 10^{6}\right.$ years) the influx of groundwater will occur, leading to the deterioration of the engineered barrier system (composed of a cement backfill or clay, and the canisters in which the waste are stored). This will lead to the release and transport of low concentrations of long-lived radionuclides from the GDF and into the near-field (the surrounding host geology). It is not yet fully understood how radionuclide species will be transported from these engineered facilities when the containment is breached. In a failure scenario, it is expected that the transport of most radionuclides will be inhibited by the backfill material, which provides alkaline conditions to suppress the solubility of cationic radionuclides and a high surface area to enhance radionuclide sorption [2]. However, it has been shown that anionic radionuclide species such as pertechnetate 
$\left(\mathrm{TcO}_{4-}\right)$ and iodide $\left(\mathrm{I}^{-}\right)$are weakly sorbed by backfill cements [3 - 5]. ${ }^{99} \mathrm{Tc}$ is abundant in radioactive wastes due to its high fission yield of ca. $6 \%$ for thermal fission of ${ }^{235} \mathrm{U}$. As a consequence of its long half-life $\left(2.1 \times 10^{5}\right.$ years $)$ and high solubility of the pertechnetate species $\left(\mathrm{Tc}^{\mathrm{VII}} \mathrm{O}_{4}{ }^{-}\right),{ }^{99} \mathrm{Tc}$ is a key contributor to the potential radiological risk to future populations in post closure safety assessments.

In this study, we demonstrate a new technique for the non-invasive, quantitative imaging of the transport of technetium-99 as pertechnetate, using the $\gamma$-emitting metastable isomer, technetium$99 \mathrm{~m}$, which is commonly used in medical imaging. We quantify directly the transport of ${ }^{99 \mathrm{~m}} \mathrm{Tc}$ in lab-scale flow cells through porous media relevant to geological disposal of nuclear waste. These include: quartz sand, as a simplified analogue for sandstone and cementitious materials commonly used in nuclear waste disposal strategies, including Ordinary Portland Cement (OPC) and OPC combined with pulverized fly ash (PFA).

\section{METHODOLOGY}

Perspex flow cells $(10 \times 5 \times 0.5 \mathrm{~cm})$ were filled with either: quartz sand (Fisher, particle size 500-700 $\mu \mathrm{m}$ ); Ordinary Portland Cement; or Pulverised Fly Ash/OPC cement (5:4). Cements were prepared with a w/s ratio of 0.37 , cured at room temperature for 28 days, and crushed and sieved to a 1-2 mm size fraction. Compositions are given in Table 1. Flow cells were saturated with pH 5.7 de-ionised water and continuous flow was maintained in the cells, from top to bottom, at $0.33 \mathrm{~mL} \mathrm{~min}^{-1}$ using an 8-channel peristaltic pump, beginning 30 minutes prior to injection of the radiotracer, and for the duration of the experiment.

Table 1. Chemical compositions of main cement formulations.

\begin{tabular}{lll}
\hline Component (wt \%) & OPC & OPC/PFA \\
\hline $\mathrm{CaO}$ & 50.2 & 26.2 \\
$\mathrm{SiO}_{2}$ & 16.5 & 27.4 \\
$\mathrm{CO}_{2}{ }^{*}$ & 13.0 & 11.0 \\
$\mathrm{H}_{2} \mathrm{O}^{* *}$ & 10.2 & 12.7 \\
$\mathrm{Al}_{2} \mathrm{O}_{3}$ & 4.0 & 12.6 \\
$\mathrm{Fe}_{2} \mathrm{O}_{3}$ & 2.0 & 4.8 \\
$\mathrm{MgO}$ & 1.4 & 1.4 \\
$\mathrm{SO}_{3}$ & 1.4 & 1.2 \\
$\mathrm{~K}_{2} \mathrm{O}$ & 0.6 & 1.7 \\
$\mathrm{P}_{2} \mathrm{O}_{5}$ & 0.4 & 0.5 \\
$\mathrm{Na}_{2} \mathrm{O}$ & 0.2 & 0.5 \\
\hline
\end{tabular}

* determined by loss on ignition

** determined by loss of mass upon heating

${ }^{99 \mathrm{~m}} \mathrm{Tc}$ as pertechnetate $\left(\mathrm{TcO}_{4}{ }^{-}\right)$was produced in the hospital radiopharmacy via saline-based elution of a GE Medical Systems Drytec ${ }^{99 \mathrm{~m}}$ Tc generator. Approximately $0.2 \mathrm{~mL}$ of diluted ${ }^{99 \mathrm{~m}} \mathrm{Tc}$ was drawn into a syringe, corresponding to an activity of $\sim 15-20 \mathrm{MBq}$. The activity in each syringe was accurately measured in a Capintec CRC-15R radionuclide calibrator before and after injection so that the exact activity injected into each cell could be determined. In all cases ${ }^{99 \mathrm{~m}} \mathrm{Tc}$ activity readings were decay corrected to the time the gamma camera acquisition was started $\left({ }^{99 \mathrm{~m}} \mathrm{Tc}\right.$ half-life is $\left.6.01 \mathrm{hrs}\right)$. Imaging of the flow cells was performed on a dual-headed 
GE Medical Systems Infinia gamma camera (GE Medical, Milwaukee, WI, USA). A dynamic acquisition of 330 frames taken at $30 \mathrm{~s}$ intervals was started just prior to injection of the ${ }^{99 \mathrm{~m}} \mathrm{Tc}$ into the flow cells. Images were acquired with a matrix size of $256 \times 256$ resulting in a pixel size of $2.2 \mathrm{~mm}$. Image counts were automatically decay corrected to the beginning of the acquisition. Raw image data were calibrated using a sensitivity factor [5] to give 2-D spatial arrays of tracer concentration data. Spatial moments analysis was applied to image data for the ${ }^{99 \mathrm{~m}} \mathrm{Tc}$ to provide quantitative comparative data on radiotracer activity profile. Moments in the direction of travel were calculated using ImageJ software.

\section{RESULTS}

\section{Transport data}

First spatial moments analysis of the ${ }^{99 \mathrm{~m}} \mathrm{Tc}$ plume gives activity profiles normal to the direction of travel, as a function of distance from the injection point, and time (Figure 1). For quartz sand, the activity profiles show a fairly high degree of symmetry and no tailing in the leading or trailing edges, indicating conservative transport, i.e. the sand does not impose a significant physical or chemical impediment to ${ }^{99 \mathrm{~m}} \mathrm{Tc}$ transport. These results were reproducible across a number of flow cells with identical conditions, and also for sand that was saturated using a pH 10 buffer $\left(\mathrm{NaOH}, \mathrm{NaHCO}_{3}\right)$ [5].

The characteristics of ${ }^{99 \mathrm{~m}} \mathrm{Tc}$ transport through the saturated, crushed cement flow cells differed for each cement type. The end $\mathrm{pH}$ for all flow cells was between $\mathrm{pH} 12$ and 13. Figure 1 shows that for all of the cements, the activity profiles are asymmetric with tails on the leading and trailing edges of the peaks. This suggests that transport of ${ }^{99 \mathrm{~m}} \mathrm{Tc}$ is significantly affected physically and/or chemically by the cement, and is indicative of reactive transport. Figure 2 gives the ${ }^{99 \mathrm{~m}} \mathrm{Tc}$ activity profiles for each material tested as a function of time, normalised to the input activity, and Table 2 shows the percentage of retained ${ }^{99 \mathrm{~m}} \mathrm{Tc}$ in each material at the end of the experiment (160 minutes). These demonstrate that in the sand flow cells, all of the ${ }^{99 \mathrm{~m}} \mathrm{Tc}$ exits the cell after approximately 40 minutes. For the OPC and OPC/PFA mix, some ${ }^{99} \mathrm{Tc}$ remains in the cell at 160 minutes. Calibrated concentration distribution data for ${ }^{99 \mathrm{~m}} \mathrm{Tc}$ transport though the quartz sand, OPC and the OPC/PFA mix 40 minutes after injection are shown in Figure 3. In the saturated quartz sand, the ${ }^{99 \mathrm{~m}} \mathrm{Tc}$ tracer passed through as well-defined plumes with peak concentrations in the centre of $\sim 10 \mathrm{MBq} \mathrm{mL}^{-1}$. In the saturated cement systems, the ${ }^{99 \mathrm{~m}} \mathrm{Tc}$ tracer as transported as elongated plumes, with peak activities at the forefront of the plume of $\sim 8 \mathrm{MBq} \mathrm{mL} L^{-1}$ and $2 \mathrm{MBq} \mathrm{mL}^{-1}$ in the OPC and OPC/PFA, respectively, and activities in the tailing plumes of between 1 and $5 \mathrm{MBq} \mathrm{mL}^{-1}$.

Table 2. Percentage ${ }^{99 \mathrm{~m}} \mathrm{Tc}$ mass retention in porous media at 40,80 , and 160 minutes under flow conditions of $0.33 \mathrm{~mL} \mathrm{~min}^{-1}$, as determined by $\gamma$-camera imaging.

\begin{tabular}{llll}
\hline & & $\%$ mass retained after & \\
Material & $40 \mathrm{~min}$ & $80 \mathrm{~min}$ & $160 \mathrm{~min}$ \\
\hline Sand & 0 & 0 & 0 \\
Ordinary Portland Cement & 55 & 19 & 10 \\
Pulverised fly ash/OPC mix & 52 & 8 & 4 \\
\hline
\end{tabular}



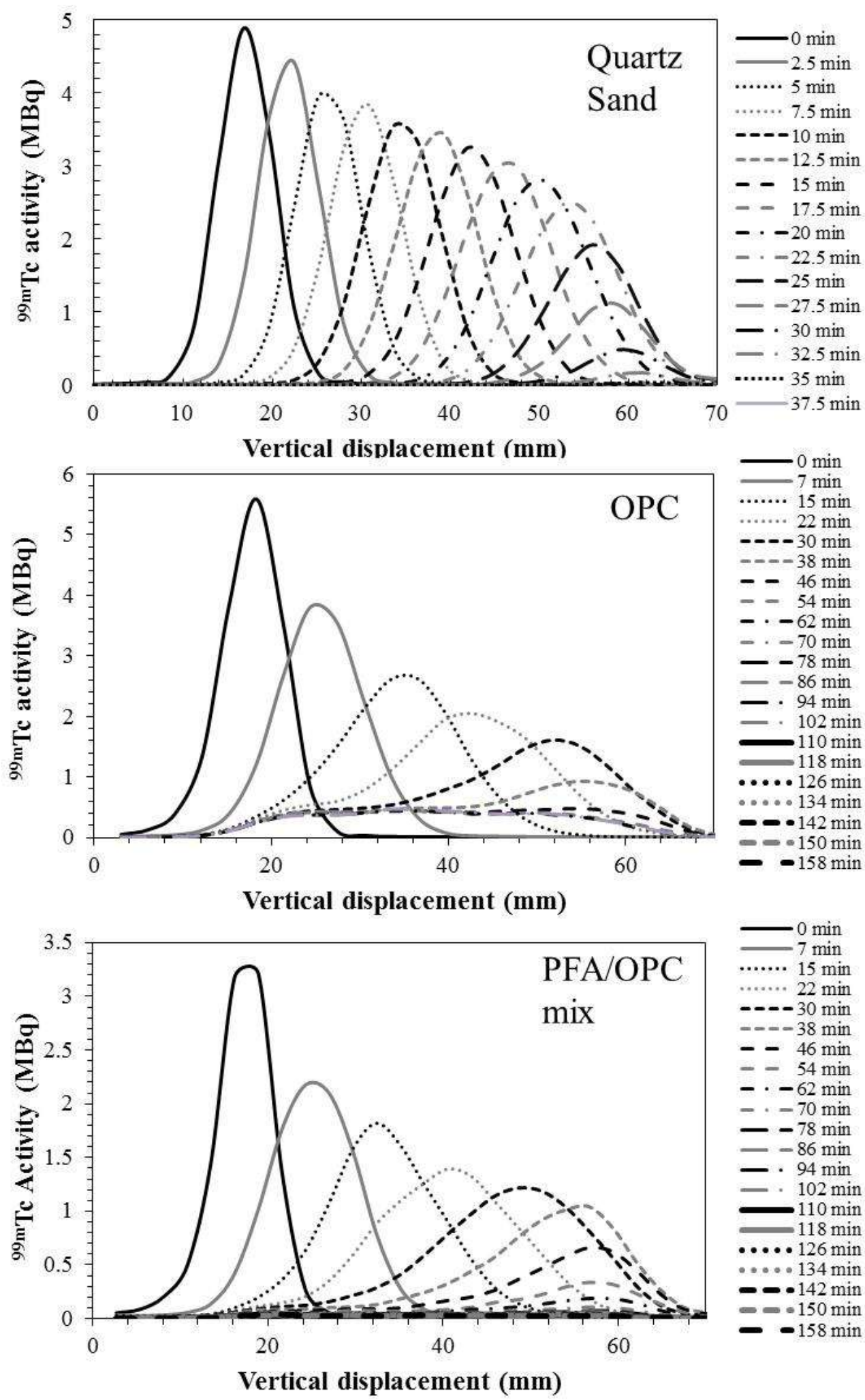

Figure 1. ${ }^{99 \mathrm{~m}} \mathrm{Tc}$ activity profiles (derived from first spatial moment analysis) resulting from flow under water saturated conditions in quartz sand, Ordinary Portland Cement (OPC) and OPC mixed with pulverised fly ash (PFA). The input activity of ${ }^{99 \mathrm{~m}} \mathrm{Tc}$ varied slightly for each flow cell. 


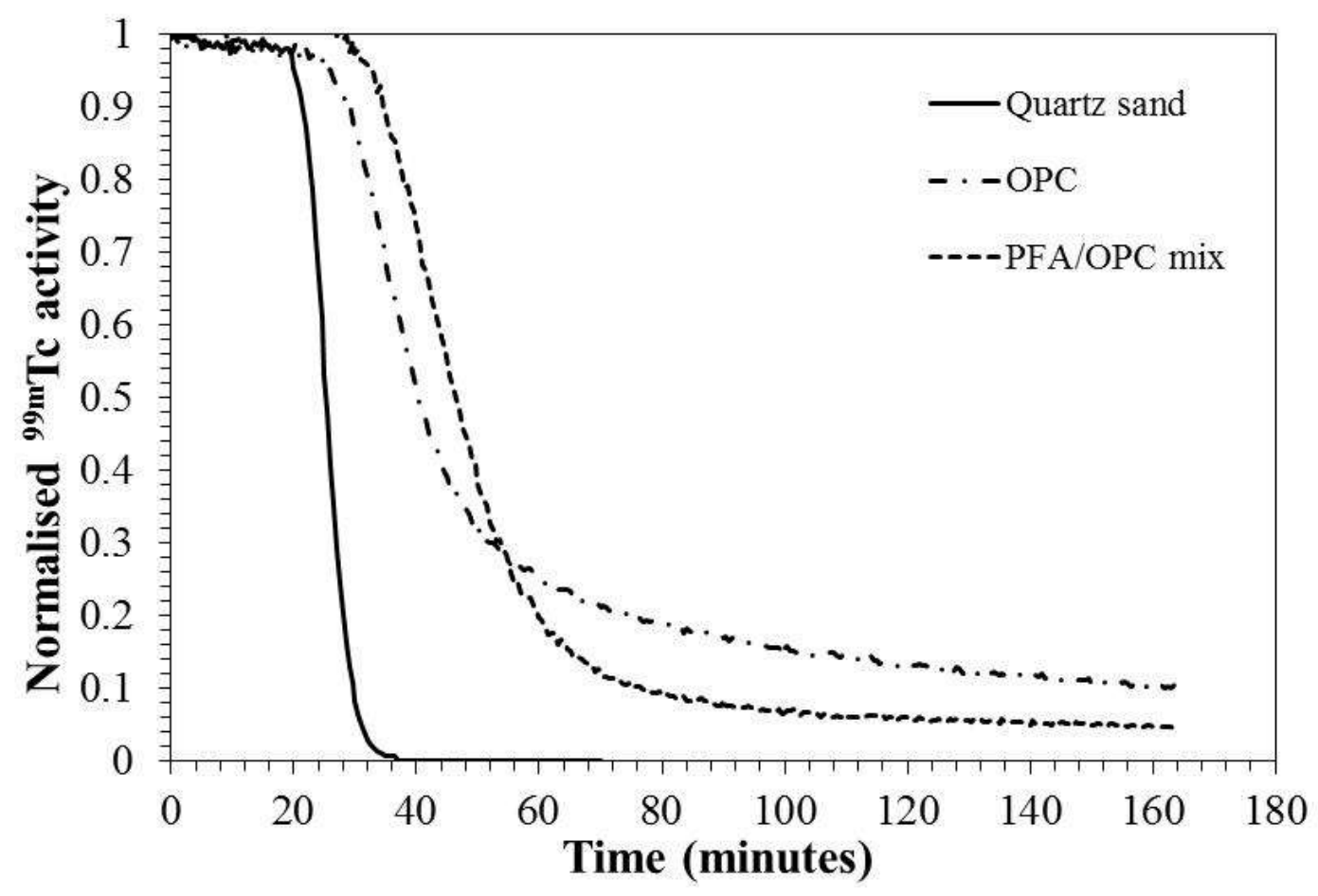

Figure 2. Total measured activity of ${ }^{99 \mathrm{~m}} \mathrm{Tc}$ (normalised to input activity) as a function of time during transport through quartz sand, Ordinary Portland Cement (OPC) and OPC mixed with pulverised fly ash (PFA).
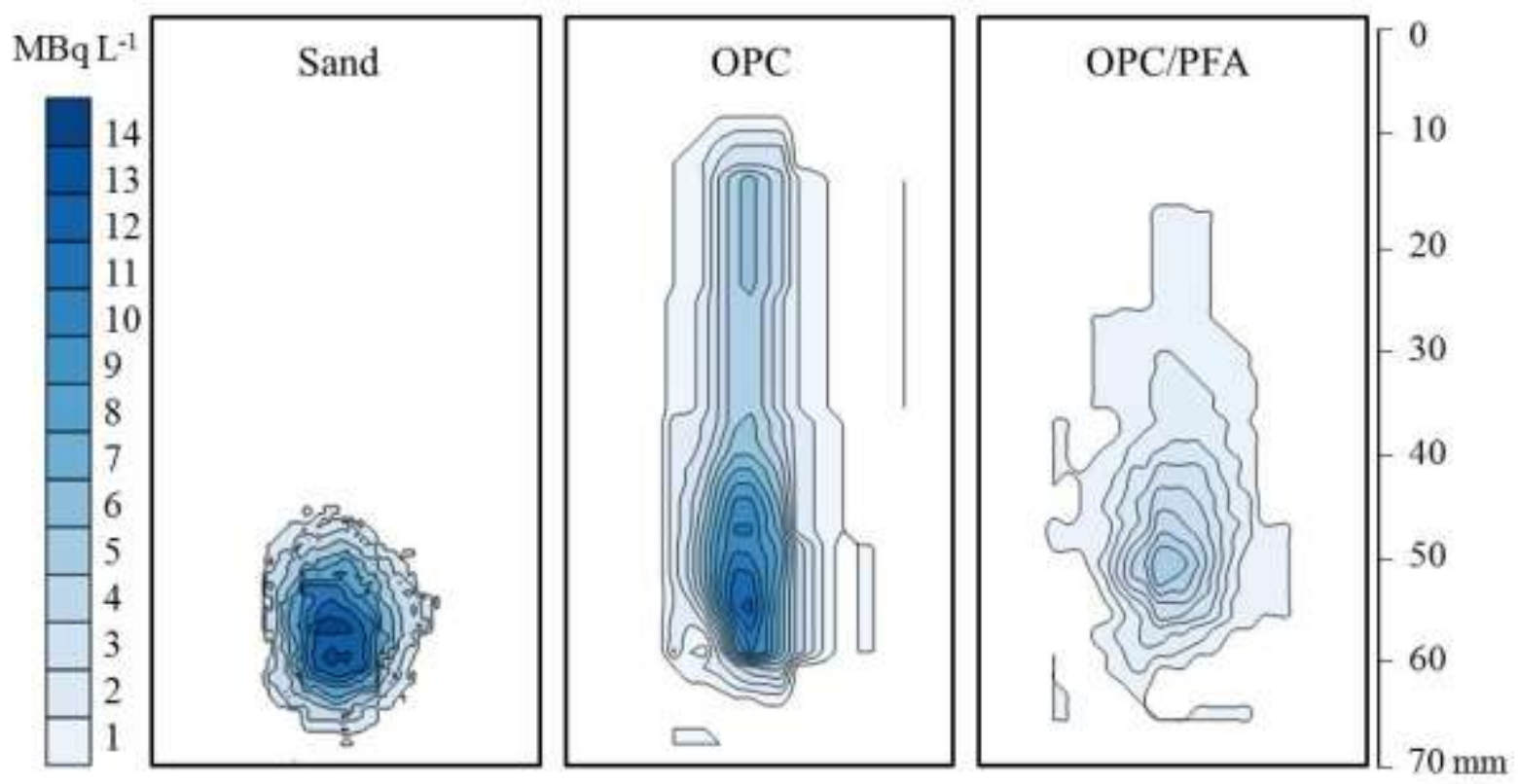

Figure 3. Calibrated concentration distributions derived from gamma camera images of ${ }^{99 \mathrm{~m}} \mathrm{Tc}$ activity in quartz sand, Ordinary Portland Cement (OPC) and OPC mixed with pulverised fly ash (PFA) at 40 minutes after the injection of ${ }^{99 \mathrm{~m}} \mathrm{Tc}$. 


\section{DISCUSSION}

\section{Transport and immobilization of technetium}

Quartz sand demonstrated poor retardation of ${ }^{99} \mathrm{~m} \mathrm{Tc}$ and conservative transport characteristics were displayed. This is unsurprising, due to the net negative surface charge of sand under the conditions in this study. Since the pertechnetate anion is also negatively charged, chemical sorption is prevented by repulsive electrostatic interactions [5]. As a simplified analogue for sandstone rock, results from this study suggest that should technetium be released from a GDF, it may be transported freely by groundwater. This result highlights the importance of the engineered components within the geological disposal facility, and in particular, the backfill material, to sorb and mitigate the transport of this radionuclide. Transport of the ${ }^{99 \mathrm{~m}} \mathrm{Tc}$ tracer through the cement materials was slower and more dispersed than in the sand, as shown in Figure 2. As noted, the data indicate reactive transport of the ${ }^{99 \mathrm{~m}} \mathrm{Tc}$ through the cement, with approximately $4 \%$ and $10 \%$ of the injected tracer remaining in the cement after 160 minutes in the OPC and OPC/PFA, respectively (Table 2). The normalised activity profiles shown in Figure 2 suggest that should the experiment continue for a longer period of time than allowed by the $\gamma$ camera, all of the ${ }^{99 \mathrm{~m}} \mathrm{Tc}$ tracer would eventually exit the cell.

There was no sorption of ${ }^{99 \mathrm{~m}} \mathrm{Tc}$ onto the OPC/PFA cement as it passed through the flow cell (indicated by the constant decrease of ${ }^{99 \mathrm{~m}} \mathrm{Tc}$ tracer in the flow cells, Figure 2). This is in contrast to previous work that found that a PFA/OPC mix at a ratio of 1:1 was capable of sorbing almost all of the ${ }^{99} \mathrm{Tc}(\mathrm{VII})$ present in anaerobic, static batch experiments over a period of several months [4]. Previous studies have shown that Fe(II)-bearing minerals readily reduce Tc(VII) to Tc(IV) under reducing conditions $[6,7]$, therefore, it might be expected that the high Fe(II) content of PFA ( $\sim 5$ wt $\%$ in the current study, Table 1$)$ may lead to a reduction of ${ }^{99} \mathrm{Tc}$ to insoluble, lessmobile Tc(IV). However, the redox conditions measured in the batch experiments described in [4] were found to be sufficiently positive for Tc(VII) to be the dominant oxidation state ((-110 to $+60 \mathrm{mV}$ ), implying that sorption to these cements was not via a reduction mechanism. These authors could not conclude a possible sorption mechanism. It is possible that the high sorption achieved in the batch experiments in [4] compared to the flow cell study described in the current study may be due to the smaller particle size of cement used $(250 \mu \mathrm{m}$ to $500 \mu \mathrm{m}$ compared to $2 \mathrm{~mm}$ to $4 \mathrm{~mm}$ particles), leading to enhanced surface area for sorption in the batch experiments. However, in a study investigating the sorption of Tc(VII) to PFA alone (i.e. with no OPC added), particle size was not found to influence the sorption capacity [8].

It can be hypothesised that the high rates of transport used in the flow cells are such that sorption is reversible, compared to static batch methods. Further work is required to elucidate this, and to determine any possible sorption mechanisms. This work will aim to determine the effects of transport on ${ }^{99} \mathrm{Tc}$ sorption using a cement composition that is known to strongly sorb $\mathrm{Tc}(\mathrm{VII})$ : an OPC Blast Furnace Slag (BFS) mixed cement (e.g. [9, 10]). This cement produces reducing conditions (Eh of $\sim-300 \mathrm{mV}$ [11]) as it contains high concentrations of sulphide, and has been shown to form insoluble Tc(IV)-S phases [9, 10, 12]. 


\section{Gamma camera imaging development}

We have presented a new methodology that enables rapid measurement of the $\gamma$-emitting radionuclide ${ }^{99 \mathrm{~m}} \mathrm{Tc}$ in porous media. Using this technique, we were able to quantitatively measure the movement of this radionuclide in flow through opaque natural and engineered materials relevant to nuclear waste geological disposal scenarios. Further work is directed towards interpretation of this data by simple conservative transport models, and in the case of cements that sorb ${ }^{99 \mathrm{~m}} \mathrm{Tc}$, reactive transport models. This novel quantitative methodology has the potential to rapidly and conveniently characterize design options for backfill materials, and to enhance the sorption capabilities of backfill materials towards anionic radionuclides such as ${ }^{99} \mathrm{Tc}$.

\section{ACKNOWLEDGMENTS}

The research leading to these results has received funding from EPSRC Grant EP/F055412/1: Decommissioning, Immobilisation and Management of Nuclear Wastes for Disposal (DIAMOND). N. C. Hyatt is grateful to The Royal Academy of Engineering and the Nuclear Decommissioning Authority for funding.

\section{REFERENCES}

1. Geological Disposal: Steps toward implementation, Nuclear Decommissioning Authority, Report number NDA/RWMD/013, March 2010.

2. Development of the Nirex Reference Vault Backfill; Report on current status in 1994, United Kingdom Nirex Limited, Report number S/97/014, 1997.

3. S. Bayliss, R. McCrohon, P. Oliver, N. J. Pilkington and H. P. Thomason, Near-field sorption studies: January 1989 to June 1991. AEA Report NSS/R277, 1996.

4. S. Baker, A. Green and S. J. Williams, The removal of technetium(VII) from alkaline solution by NRVB, PFA/OPC and BFS/OPC. Serco Assurance Report SA/ENV-0606, 2004.

5. C. L. Corkhill, J. W. Bridge, X. C. Chen, P. Hillel, S. F. Thornton, N. C. Hyatt, S. A. Banwart. Energy and Environ. Sci., Submitted 2012.

6. G. Lear, J. M. McBeth, C. Boothman, D. J. Gunning, B. L. Ellis, R. S. Lawson, K. Morris, I. T. Burke, N. D. Bryan, A. P. Brown, F. R. Livens and J. R. Lloyd, Environ. Sci. Technol., 2010, 44, 156.

7. D. Cui and T. E. Eriksen, Environ. Sci. Technol., 1996, 30, 2259.

8. M. M. Cowper, A. Green and S. W. Swanton, The removal of Tc(VII) from alkaline solution by pulverised fly ash. Serco Assurance Report SA/ENV-0651, 2004.

9. P. G. Allen, G. S. Simering, D. K. Shuh, J. J. Bucher, N. M. Edelstein, C. A. Langton, S. B. Clark, T. Reich and M. A. Denecke, Radiochim. Acta 1997, 76, 77.

10. W. W. Lukens, J. J. Bucher, D. K. Shuh and N. M. Edelstein, Environ. Sci. Technol, 2005, 39, 8064.

11. F. P. Glasser and M. Atkins, MRS Bull., 1994 XIX, 33.

12. Y. Liu and S. Jurisson. Radiochim. Acta, 2008, 96, 823. 